\title{
明治天皇行幸における華族邸宅の能楽御覧所について THE STUDY ON NOH SPACE OF NOBLE RESIDENCE FOR ENTERTAINING MEIJI EMPEROR
}

\author{
奧冨利 幸* \\ Toshiyuki OKUTOMI
}

\begin{abstract}
In this study, I analyze the composition of Noh space (in Japanese named as Nohgaku-golan-jo) of nobility residence in the Meiji period. Nohgaku-golan-jo is an Ima (room) for daily life, but it is changed to a place to watch Noh when Emperor visiting. At first, I clarify when and where and how many times Noh were played as entertainment events for entertaining Meji Emperor, by using the official documents "Meji Tenno ki". The second, I examine the space of Nohgaku-golan-jo, for example, how is the surrounding of Noh stage, how the stage being layout with the main building, more further, when events was opening how to use the spaces including the other rooms of the residence. I take up Toshinari Maeda's house as a case of nobility residence, because there left rich documents recording the event for Emperor. In addition, comparison the Noh event for the general visiting at Edo era, I will make clear what part of the event space to play Noh was changed in Meji era.
\end{abstract}

\section{Keywords: Noble Residence, Noh Stage, royal visit, Meiji Emperor} 華族邸宅 能舞台 行幸 明治天皇

\section{1. はじめに}

本研究では、明治期の華族邸宅への天皇行幸における能楽御覧所 について検証を行いたい。まず、天皇行幸の供応行事としての能楽 が、どの程度実施されたのかを確認するために、明治天皇に関する 最も公式な記録である『明治天皇紀』によって、年代と場所と回数 の分析を行う。次に、行幸における諸室の構成や使われ方について、 能楽御覧所の能舞台周辺の状況も含めて考察したい。具体的には、 明治期での行幸のうち、『明治天皇紀』でもっとも詳細に記録され、 明治期最後の行幸能として行われた 1910 年（明治 43 年） 7 月 8 日 の前田利為邸の行幸を代表事例として取上げ、検討を行う。また、 江戸時代において、明治期の天皇行幸と類似した先行行事である将 軍御成について、そこで行われた能楽御覧を採り上げ、御成におけ る能楽御覧の次第について、邸宅の使われ方と関連させて分析を行 う。具体的には、1698 年（元禄 11 年） 3 月 18 日の尾張家江戸堿町 邸における綱吉の将軍御成を取上げる。そして、両行事での能楽御 覧の次第と邱宅での能楽御覧所の構成を比較することで、明治期の 華族邸宅における能楽御覧所がどのような歴史的経緯をもって形成 されたのか、さらに、明治期の皇室と華族の絆を取り持った天皇行 幸において、能楽御覧が担った役割の重要性を実際の行幸行事の次 第を検証することで明らかにしたい。

\section{2. 天皇行幸と能楽御覧}

明治天皇は、行幸によって日本各地を巡り、明治維新後の日本を つぶさに見て歩かれた。1868 年（明治元年）の御東幸、京都還幸、
1872 年 (明治 5 年) の中国、西国巡幸、1876 年（明治 9 年）の東北 巡幸、1878 年（明治 11 年）の北陸東海巡幸、1880 年（明治 13 年） の山梨、三重、京都巡幸、1881 年（明治 14 年）の奥羽、北海道巡 幸、1885 年（明治. 18 年）の中国巡幸などにより、北は札幌から、 南は鹿児島までを巡幸されている注1。こうした全国各地への巡幸の 合間には、東京で華族邸宅に行幸する機会を持ち、行幸に際して能 楽が催されることが恒例であった。また、『明治天皇紀』では、天皇 以外に、皇太后や皇后、皇太子の行啓での能楽御覽も記録されてお り、能楽御覧が行幸啓における重要な行事として定着していたこと が伺える。明治天皇紀能楽関連年表（表－1）によると、1876 年（明 治 9 年) 4 月 3 日の岩倉具視邸の行幸における能楽御覧を皮切り注 2 に、1912 年（明治 45 年）6月 10 日の皇后の靖国神社能楽堂行啓に 至るまで、実に 85 回の行幸啓における能楽御覧が記録されている。 このなかで、特徵的な点が二つある。一つは、85回の能楽御覧のう ち、明治天皇の行幸における回数は 33 回、皇太后の行啓における回 数が 47 回と天皇のそれを上回っていること。そして、皇太后は 1897 年 (明治 30 年) 1 月 11 日に崩御されているから、明治天皇より 15 年間も短い間に、天皇より頻繁に能を御覽になったことである。も う一つは、皇太后が崩御された後に明治天皇が能を御覧になったの は、1910 年（明治 43 年） 7 月 8 日の前田利爲邸行幸時の一度だけと いうことである。つまり、能楽御覧は天皇にとって、英照皇太后と 交流する機会ともなっていたことが考えられる。そして、この点は 次のことからも裏付けられる。つまり、演能場所別の回数では、青 山御所の行幸啓が 13 回で最も多く、そのうち、明治 14 年 12 月 16

\footnotetext{
* 小山工業高等専門学校 准教授・博士 (工学)

Assoc. Prof., Oyama National College of Technology, Dr. Eng.
} 
日の演能では、天皇が奥羽と北海道の巡幸からの帰館を祝ってのも のであった注 3 。また、その他の演能場所の 34 回が、華族邸宅への 行幸啓における演能であり、能楽御覧が行幸啓における恒例の催し となっていたことがわかる。そして、記録の多くが、能楽を演じる 場所を能楽御覧所と表現しており、例外として、1885 年（明治 18 年） 12 月 26 日の有栖川宮邸に行幸では、踏舞場という表現をして おり、踏舞場が能楽御覧所に転用されたことがわかる注4。また、1891 年 (明治 24 年) 4 月 10 日の川村純義邸の行幸や、1893 年 (明治 26 年） 6 月 2 日の土方久元邸の行幸では、庭上の能楽御覧所という表 現が使われ、能楽御覧所が庭に能舞台を設けた状況を示していたこ とが伺える注 5 。この能楽御覧所の様子を知る上で貴重なのが、1910 年（明治 43 年） 7 月 8 日の前田利為邸への行幸である。

このように、明治天皇行幸による能楽御覧は、明治元年から 30 年までの間に主に行われ、能楽御覧所と呼ばれる庭上に造られた

能舞台とそれと対峙する母屋が主な構成であった。当時は、明治維 新で能楽を演じる場所が悉く失われ、1880 年（明治 13 年）の能楽 社の誕生で復興の機会が到来するが、能を演じる施設はたいいん少 なく、天皇行幸による演能が能楽師に演能の機会と場所を提供する 役割を担い、能楽の存続に大きく奇与していたことがわかる。

\section{3. 将軍御成の能楽御覧所}

明治期の天皇行幸における能楽御覧と江戸期に行われた将軍御 成の能楽御覧は、臣下が最高の賓客を招く行事での余興芸能という 点で同様であるが、定まった規則により儀式として行われた点も類 似し、さらに、臣下宅の各部屋を巡回しながら行事が進行するとい う形式も同じである。天皇行幸を賜った明治期の華族は、1869 年 (明 治2）6月 17 日の版籍奉還に伴い成立したが、公卿と諸侯を合わせ て華族という身分がつくられ、公卿は皇室の藩屏である廷臣、諸侯 は徳川幕府の封建大名であった。つまり、華族の一部は、江戸期に 将軍御成を行った家柄ということになる。つまり、行幸における能 楽御覧所は、邸宅の和館を見所とし、その前庭に能舞台を設えるが、 この配置は書院の広間を見所とし、前庭に能舞台を設えた江戸期の 『匠明』の「当代広間ノ図」(図 1）を規範とする武家屋敷の構成を 基本的に踏壟している。そこで、次に、将軍御成と天皇行幸の能楽 御覧を比較してみたい。

将軍御成では室町期になると故実書が書かれて、幕府式楽として 定着した注 6 。さらに、江戸時代になると建築技術書の普及と相俟っ てその完成度を高めた。「当代広間ノ図」では、広間の上段の間の正 面白州に能舞台を配置している。将軍御成では、武家屋敷の様々な 場所を巡って進行するのであり、広間の西奥は、客の居間に当たる 「御成御殿」、能舞台のある白州を挟んで南側に「スキヤ」、つまり 茶室がある。こうした接客部分は、武家屋敷全体の面積の約三分の 一を占めており注 $7 、$ 他の主人、家来、女中の日常生活部分と完全に 独立し、使われ方は、殿舎ごとに分類することができる注 8 。大広間 では、謡始、嘉定、将軍宣下、外国使臣謁見、能楽などであり、白 書院では、玄猪、舞楽、管絃、踣鞠、武術など。黒書院では、連歌 御会、碁御覧など。御座所では、夏越しの戨、煤掃、節分、元服な どである。つまり、能舞台が対峙した大広間は、接客部分の中で、 最も公式な謁見の場所であったことがわかる。

次に江戸時代における将軍御成の事例として、1698 年（元禄 11
表 1 明治天皇紀能楽関係年表

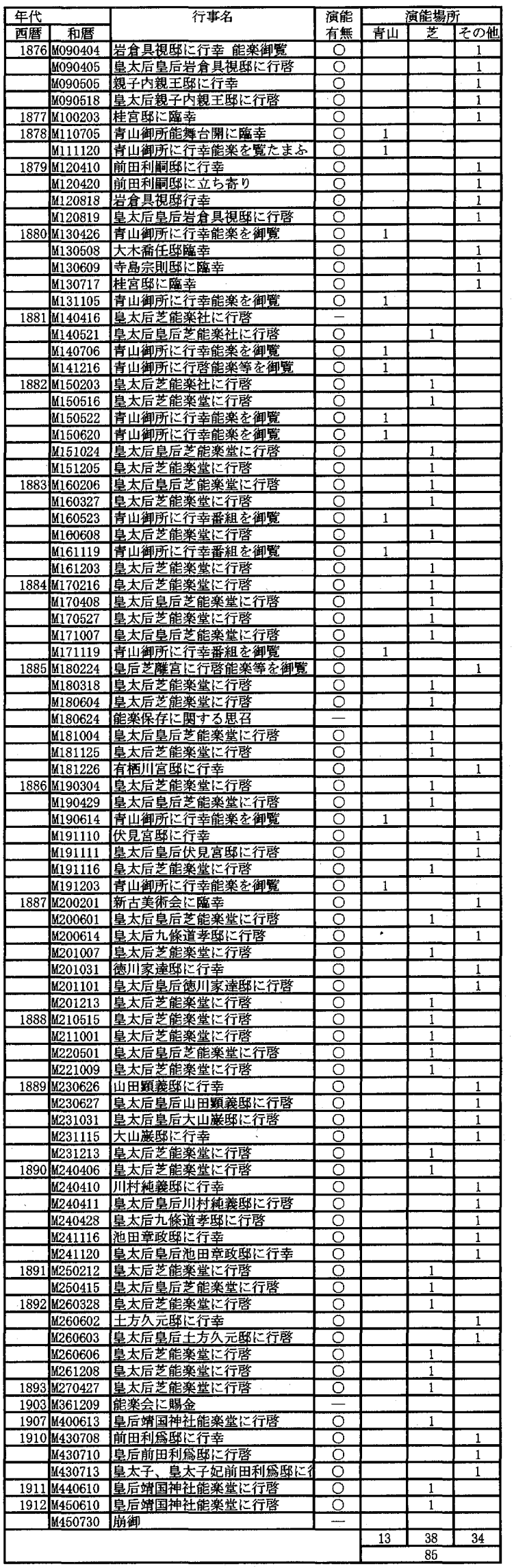

注 : 和糜の M090403 は明治 9 年 4 月 3 日を示寸。演能有無は，○が有，一が 無を示す。演能場所は, 青山が青山御所能舞台, 芝が, 能楽社, 能楽堂, 靖 国神社能楽堂を示す。 
年） 3 月 18 日の尾張家江戸趎町邸における綱吉の御成注 9 を確認し たい。(1)御成書院で刀などを下賜。(2)表書院で献上品の献上。(3)御 成書院で三献之儀と賜物、献物の授受、七五三の膳、千代姫との対 面。(4)休息間で献上品の献上。(5)御成書院で「論語」の講演注 10 。 (6)表書院で能楽の御覽、能三番、狂言二番を御覧。(7)休息之閒で休 秝、香炬や絵を所望に応じて献上。(8)御成書院で仕舞注 11 。御成書 院では、綱吉と網誠も舞を披露し、ここでの能は表書院より娛楽性 の強い催しであった。こうして、将軍御成は、御成書院一表書院一 御成書院一奥小座敷一休息之間一御成書院一表書院一休息之間一御 成書院と部屋を移りながら進行し、能楽御覧では、場所も性質も異 なる催しが 2 回あり、能楽師のみが演じる 1 回目と能楽師のほか、 将軍と邸主や家臣が演じる 2 回目が行われた。このように、江戸時 代の武家屋敷における能舞台とその周辺の演能空間は、基本的に御 成の規式での演能の故実と建築規範書によって強く規定され、江戸 期を通じて沓襲された。しかし、この尾張家江戸㨍町邸の網吉の御 成では、接客の中心が広間から書院に変化して、能舞台の位置は広 間上段前から表書院前に変化している注 12 。これは、武家屋敷の配 置構成が「匠明」の定める規範から徐々に離れ、自由度が増すこと で、能舞台と見所たる書院の関係に微妙な変化が生じるようになっ たことを示す。こうした変化の要因として、能は武家式楽の儀式と して役割を担うほかに、日常生活では趣味や教養として行われたた め、当初は儀礼が強く意識された広間と前庭の能舞台という配置構 成から、書院からの庭の眺望も重視するといった居住性や趣味的志 向が強くなったことが考えられる。

\section{4 、天皇行幸の能楽御覧所}

『明治天皇紀』に記録されている能楽御覧では、その実施数の約三 分の一が華族邸で行われている。そのうち、明治期の能楽の復興に 大きく貢献した前田家の事例を通して、天皇行幸の能楽御覧場につ いて検討を進めたい。前田家の本拠地注、加賀宝生で知られる能楽 の盛んな土地柄であるが、13 代当主の前田斉泰は、明治期の能楽界 の一大行事であった岩倉邸の天覧能で演能したのを初め、能楽社の 創設では発起人として中心的な役割を担った。明治初頭の前田家に は本郷に本邸、根岸に別邸があった。本邸は元々 1616 年 (元和 2 年) に第三代利常が、加賀下屋敷として幕府より賜ったことに始まり、 1657 年（明暦 3 年）の大火で辰の口の上屋敷が焼失してからは、こ こが上屋敷として使われていた注 13 。行幸は本郷本邱で行われたが、 根岸別邸においても、大正期に外国賓客の訪問があった。1910年 (明 治 43 年) 7 月 8 日の前田利為邸行幸啓恃明治期における盛大な行幸 の一つであった。この行幸を主催した前田利為は、1885 年 (明治 18 年) 6 月 5 日に旧七日市藩前田家第 12 代前田利昭の 5 男茂として生 まれ、東京で教育を受けていた。このとき本家に当たる旧加賀藩前 田家第 15 代前田利嗣は、病床にあって後嗣となる男子がおらず、茂 を養子として迎えた。1900 年（明治 33 年）6月 13 日に 16 歳であっ た茂が盖子となって、前田家 16 代侯爵前田利為を襲名した。実は、 先代の利䐀には、前田邸一の行幸を実現させるという宿願があった という。つまり、以前の 1879 年（明治 12 年） 4 月 10 日に前田利嗣 邸行幸があり、このときには、東京府北豊島郡王子村にあった印刷 局抄紙部に、右大臣岩倉具視、参議井上馨、大藏卿大隈重信が伴い 行幸した帰りに立ち寄り、太政大臣三條實美と熾仁親王が利嗣邸で

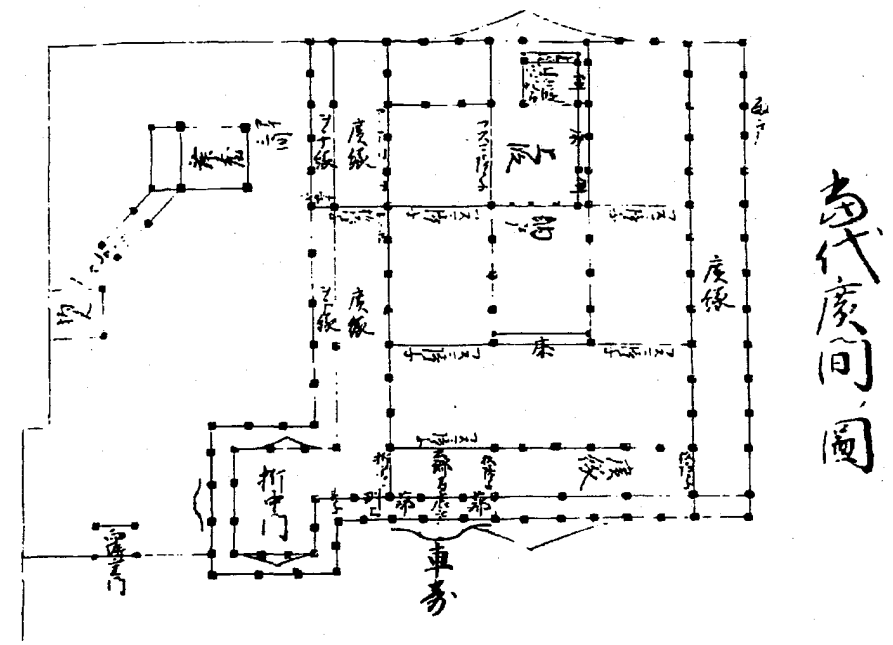

図 1 当代広間の図（日本建築学会編『日本建築史図集』彰国社）

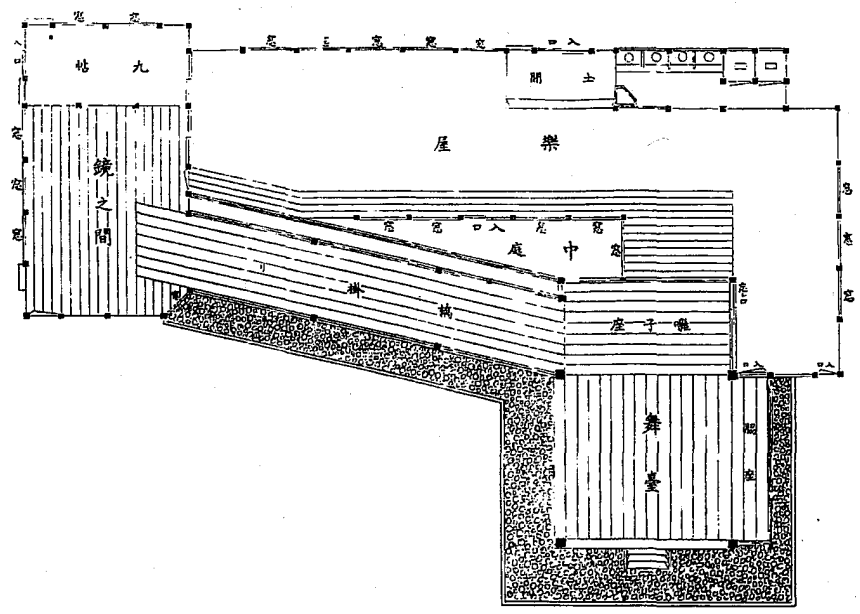

図 2 前田家本鄉邸能舞台平面図 (『能楽』11 巻 5 号)

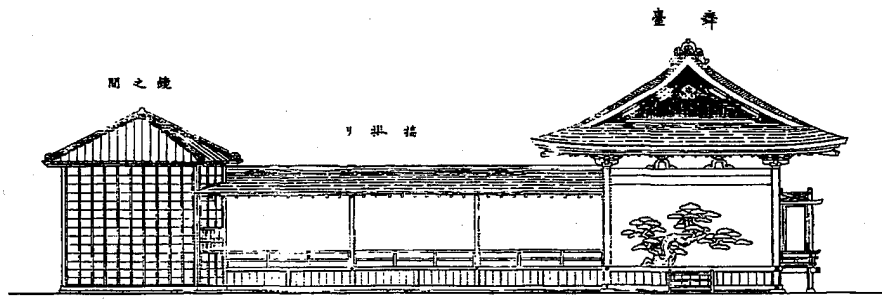

図 3 前田家本郷邸能舞台正面図 (『能楽』11 巻 5 号)

合流し、利哃家族の拝謁、下賜の後、能楽御覧所で能楽を㕡覧し、 晚餐と献品の後に午後 8 時に還幸された。また、同年 4 月 18 日には、皇太后、皇后が同じく印刷局抄紙部に行啓の際に利嗣邸に 立ち寄り、能楽を御覧になっている注 14 。そして、再度の行幸を望 んだのである。それを受けて、利為は、1899 年（明治 32 年）1 月家 政評議会注 15 に諮って、「本郷邸 $习$ 永遠ノ本邸卜定メ、第宅 $习$ 改築又 ル事」注16 として、本邸の新築と仮住居の建設を決定した。同年 12 
月に起エし、途中で日露戦争による中断はあったが、1905 年（明治 38 年) 12 月に和館が、1907 年（明治 40 年） 12 月に洋館が竣工した。 そして、1910 年（明治 43 年）1 月 11 日に前田利為邸行幸啓の内意 を受けた。したがって、実に行幸の 10 年以上も前から行幸に向けた 淮備が始まっていたことになる。また、行幸啓の準備に当り、先に 行幸を賜った鍋島、井上侯爵家と土方伯爵家等から行幸記録一件を 借用して参考とし、宮内省との連絡を密にとって淮備作業が進めら れた注 17 。したがって、明治期の行幸啓では、基本的に前例を参考 として、宮内省と綿密な打合せの上で、当日の会場や進行が決めら れていたことがわかる。

新築された前田利為邸は、当期の華族邸宅の代表的な形式であっ た和洋館併置式の住宅であった。工事では、洋館(図 4)の設計と工 事の総監督を海軍技師で工学博士の渡辺譲、和館の設計と監督を海 軍技師の北沢虎造、洋館施工責任者に赤石真を選任した。

また、庭園構築と洋館内部装飾は、建物完成後に実施されるが、 庭園に関しては、「染井の庭彦」として知られていた伊藤彦右衛門の 二代目、伊藤嘉市が担当した。また、洋館内部装飾はフランスでの 留学を終えて帰国した野口駿尾が、玄関左右の武将像は美術学校教 授の沼田一雄が担当した。能舞台は、和館の東南隅の座敷に北面し て建てられ、能舞台の周囲は塀で仕切られ、脇正面側には、舞台と 橋掛りに向かって見所である座敷が設けられている。そして、能舞 台の周囲には、陪覧者のために仮設の屋根が架けられていた。

こうして、行幸のために設けられた能舞台は、和館の広間に対峙 する形で設けられていた。このときも、能楽御覧所という表現が成 されているほか、能舞台については、「能樂は天覧餘興中主なるもの にして、其の舞臺は百二十餘日の日子と二萬二百圓の巨資と投じて 新たに造る所」と造営に力が注がれていたことが分かる。

行幸当日の行事進行を前田利為邸行幸進行表（表 2)にまとめた。 まず、表の縦軸に行事次第が時間の経過順に並心゙、入御が 11 時 12 分過ぎ、還御が 6 時 57 分であったので、 8 時間程度の行幸であった ことがわかる。また、横軸には、建物の各室名称を記載した。但し、 参考資料によって室名表記が異なるため、各資料の室名をそのまま 表記し、その下に典拠を示した。図内の印は、天皇、または、その 使者が各行事で在室された室を示しており、各印を結ぶ線は、天皇 またはその使者の移動経路を示す。

行事次第を眺めると、行事の内容は、拝謁、下賜、献上、絵画 · 家什御覧、能楽御覧、琵琶演奏、息・晚餐などであり、「儀」と「宴」 を巧みに組み合わせている。これは将軍御成における構成との類似 性が伺える。前田家では初代利家の時代から将軍御成を受けており、

1593 年（文禄 2 年） 9 月 29 日には豊臣秀吉、1617 年（元和 3

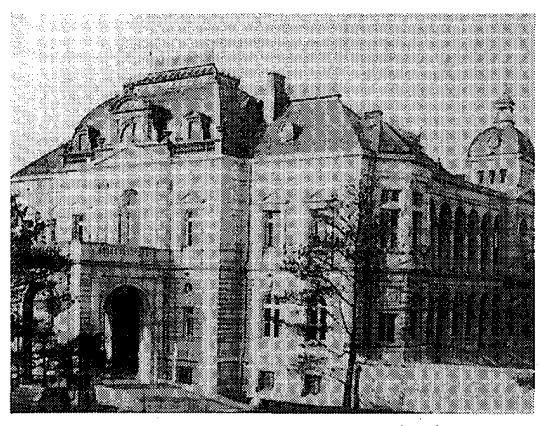

図 4 前田本郷邸洋館（『能楽画報』 2 巻 8 号)
表 2 前田利為邸行幸進行表

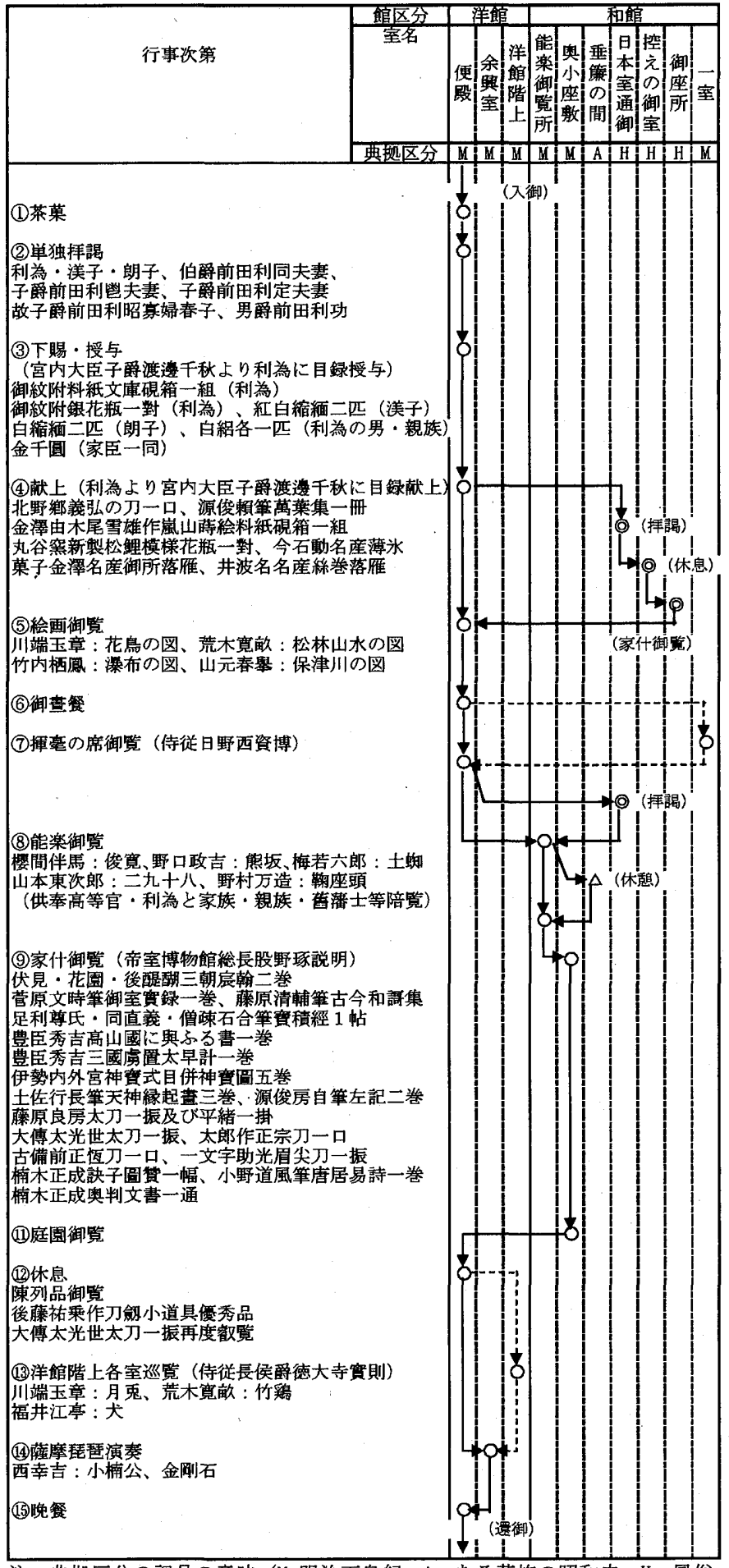

注：典拠区分の記号の意味 (M:明治天皇紀, $\mathrm{A}$ : ある華族の昭和史, $\mathrm{H}:$ 風俗 画報 411 号)，図中の接続点の意味 ( $\mathrm{O}$ : 明治天皇紀， $\triangle$ : ある華族の昭和史， (○) : 風俗画報 411 号), 図中の矢印の意味（実線 : 天皇の移動, 点線 : 天皇の 命による侍従の移動)

年） 5 月 13 日には、徳川秀忠の御成があった。秀忠の御成では、茶 事、式三献、賜物、献物、演能、饗膳が、数奇屋、御成書院と広間 を順次移動しながら進行した。また、将軍御成では、「御成書院」で 「儀」の中心である「式三献」などの行事が行われたが、天皇行幸 では、西洋館に「便殿」を置き、そこの玉座で中心行事である「謁 見」を行っているため、「御成御殿」と「洋館」、広間」と「和館」 
という対応関係が見てとれる。明治期の和洋併置式邸宅では、一般 に「洋館」を迎賓、「和館」を生活の場として使っていたわけである が、行幸の要となる便殿を洋館に置いたことは、洋館を迎賓館とし た当時の使われ方を裏付けている。また、昼・晚餐での準備では、 宮内省大膳課の職員が前田家の膳所で調理しており、当時の洋館で は、料理をする際のにおいや音を嫌って、屍房を設けなかったこと がわかる。つまり、調理を和館の膳所で行い、洋館まで運び入れた わけである。また、前田邸の玄関は西向きで、南側に洋館、北側に 和館の玄関があって、「迎賓館」としての洋館の方が道路から近くに 配置されていた。便殿は行幸での常座であるが、洋館の 2 階に設置 され、ここから各行事を行う部屋に移動したのである。当日の行幸 の進行では、洋館玄関に馬車をつけ、天皇が便殿に入る。茶菓は、

「御成」の茶事で、まずは小休頂き、その後、前田家の家族と一族 が拝謁を賜る。そして、天皇から下賜品を頂戴し、前田家から献上 品を奉る。その後、『明治天皇紀』注 18 では、絵画御覽となり、予め 用意された画家の作品を便殿で御覧になるが、『風俗画報』主 19 の記 事では、御昼餐の前に、和館に通御の際に拝謁し、御休息の後に家 什御覧になっている。続いて、揮毫の席を御覧になった後、便殿に 戻って昼餐となる。『明治天皇紀』では、昼餐の間に、侍従日野西資 博を揮毫の席に使わせており、内容が異なる。そして、能楽御覧所 に出御するのが、午後 1 時 55 分である。また、能楽御覧所に出御す る際に拝謁があったことが『風俗画報』と『前田利為』に記録され ているが、『明治天皇紀』には記載がないため省略された可能性が高 い。続いて、能楽御覧の途中、天皇が「垂簾の間」で休息されたこ とが『ある華族の昭和史』注 20 に記載されているが、この点も『明 治天皇紀』には記録がない。その後、家什御覧は、各記録とも一致 している。また、庭園御覧に『明治天皇紀』では、「宸睩を新造の庭 園に賜うこと霎時」とあり、庭園には出御せずに御覧になったと解 釈できるが、『前田利為』においても、「同陳列館縁側より瀑布の景 観を䜭覧あって」とその点が確認できる。続く休息中には、洋館階 上各室巡覧に侍従長徳大寺實則を遣わせている。その後の薩摩琵琶 の演奏の後に便殿にて晚餐をとられて環御された。この行幸の様子 は、行幸絵巻物として、「臨幸画巻」が作成された。この画巻は、岡、 倉天心を顧問として、下村観山が作画、詞書は永山近彰の記事を幸 田露伴が校正し、尾上柴舟筆致により 1928 年（昭和 3 年）9月に完 成した。この画巻を見ると行幸で各室に展示された前田家秘蔵の文 書や所蔵品を見ることができる。

その後、前田家本邸の能舞台は、1923 年（大正 12 年）9月に起 こった関東大震災で、宝生家の能舞台が焼失する事態から、宝生会 より能舞台の貸与を求められた。前田家では、当初行幸記念物であ った能舞台の貸与には慎重論があったが、当主利為の意向により、 三年間の貸与が決定された。結局、この能舞台は太平洋戦争で焼失 するまで宝生流で使われることになった。

\section{5. まとめ}

華族邸宅の能楽御覧所の建設は、江戸期の将軍御成御殿の基本的 形式、つまり、将軍が城の御殿や武家屋敷などの書院居間から白州 に建つ能舞台で演じられる能を観ていたことが、明治期に受け継が れたことがわかった。さらに、将軍御成では、御成御殿と能舞台は 新築されて将軍を迎えたが、その規範は「匠明」などの技術書で定
められていたが、明治時代になって、将軍御成と類似した天皇行幸 が行われるようになると、旧来通りに能舞台を準備して、供応芸能 として能が演じられたのである。そして、1876 年（明治 9 年） 4 月 4 日の岩倉邸での行幸で、初めて能が行われたことにより、明治期 を通して続けられる天皇行幸における能楽御覽が催されることの前 例となり、その後の行幸の次第を規定することになった。しかし、 能楽御覧所は従前のまま継承されたわけではなく、明治期の華族邸 宅の代表的形式であった和洋館併置式の住宅において、行幸時には、 「洋館」においては「儀」に当たる儀礼行事、また、「和館」におい ては「宴」に当たる遊興行事を中心に割り当て、洋館と和館を往復 して行幸行事を進行させたことがわかった。したがって、和館と前 庭の能舞台とその周辺空間で構成された能楽御覽所は、行幸行事に おける遊興の中心的な場であった。前田家本邸の行幸では、能楽御 覧所として和館の東南隅の前庭に北面した能舞台が当てられたが、 白州には大勢の陪覧者が観能できる場所が設けられた。こうした状 況は、明治時代の行幸における能楽観覧所に共通する課題であった。 そして、陪覧者が皇族や大臣、侍従や官僚であったことから、陪覧 席には仮設の屋根でかけられたが、この点については、邸宅の能舞 台周囲の観覧所の室内化の傾向として、能楽堂との関連を含めての 検証が必要と考えられる。

注

1）明治天皇巡幸日誌は、星野武男『明治天皇行幸史録』東京潮書房, 1931 年 12 月発行など。

2）宮内庁『明治天皇紀第三』吉川弘文館，1969 年 12 月発行，p 585，1876 年 (明治 9 年) 4 月 3 日に、「蓋し東京に於て能樂を天覧ありしは是れを 嚾矢と為す」とあり、遷御後初めての能楽御覧であり、その後の行幸に おける定例行事のさきがけとなった。

3) 宮内庁『明治天皇紀第五』吉川弘文館, 1971 年 3 月発行, p 587, 1881 年 (明治 14 年) 12 月 16 日「皇太后、青山御所に於て能楽を催させらる、 山形秋田両県・北海道巡幸の了れるを祝したまはんがためなり」とある。

4）宫内庁『明治天皇紀第六』吉川弘文館, 1971 年 11 月発行, p 520, 1885 年 (明治 18 年) 12 月 26 日「親王踏舞場に能楽を張り、金剛・宝生・梅

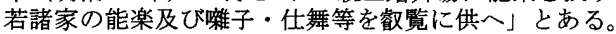

$5 ）$ 宮内庁『明治天皇紀第七』吉川弘文館, 1891 年 4 月 10 日川村純義邸行 幸「庭上設くる所の能楽御覧所に臨御」また、同じく、1893 年 (明治 26 年) 6 月 2 日の土方久元邸行幸「庭上の能楽御覧所に出御」とある。

6) 佐藤豊三「将軍家「御成」にういて (一)一室町将軍家の御成一」『金䰹鋠 書』

7）太田博太郎『匠明』にみる書院造の配置」『書院造』東京大学出版会, 1966 年 10 月 20 日, $\mathrm{p} 36$

8 ) 平井聖「近世武家住宅の機能」『日本の近世住宅』鹿島研究所出版会, 1968 年 12 月 20 日, p 160

9）佐藤豊三「将軍家「御成」について（八）一徳川将軍家の御成 その三 一徳川幕府安定期の御成」『金鯱叢書』 p 321

10) 前掲注 9 , 将軍自 5 、御成先の当主一門、家臣、幕府重職の前で「大学」 「中庸」「論語」「孟子」などの儒書を講じ、1690 年 (元禄 3 年) の網吉 の牧野成賁邸御成での「大学」が初見とされる。

11）前掲注 9 ，演者は、主客である将軍網吉と邱主の尾張網誠と家臣である。

12）前揭注 8,『日本の近世住宅』 $\mathrm{p} 168$, 近世諸大名の屋敷で、表向殿舎の構 成が、接客機能により、2つの御殿になって、近世的殿舎構成の主体が 成立した。諸大名の江戸藩邸でのこの傾向は、明暦の大火による建替え 時に顕著にあらわれ、接客と対面にあてた二つの御殿の名称が「広間一 書院」から、「大書院一小書院」に変化した点を指摘されている。

13) 前田利為伝記編算委員会『前田利為』前田利為侯伝記編箘委員会, 1986 年, $\mathrm{p} 92$

14）宮内庁『明治天皇紀第四』吉川弘文館，1970 年（昭和 45 年）8月 15 日， p 650

15）前揭注 13 『前田利為』 $\mathrm{p} 95$ 「新邸を西洋館、日本館とし、起工日を十二 月二十五日、竣工を明治三十八年度中と概定」とある。

16）前掲注 13 『前田利為』 $\mathrm{p} 94$, 「明治 32 年 1 月の評議会の決定に二つの事 項を決議した。一. 本郷邸ヨ永遠ノ本邸卜定义、第宅ヨ改筑スル事。一. 豊多摩郡大久保村所有地内二、新二別荘习建築シ、韭常立退キ、随時静 美ノ所トスル事。」とある。

17）前掲注 13 『前田利為』 p 103，「一月三十日隻備業務を左のごとく十五に 区分し、それぞれに責任者を配し準備委員長の指揮下に配した。西洋 館装飾、日本館装飾、設備（能楽余興場、写真撮影、根岸土木工事、庭 園造築) 以下省略」とあり、能楽余興場も準備業務の主要項目の一つに 上げられている。

18）宮内庁『明治天皇紀十二』吉川弘文館，1970 年 8 月 15 日，p $432 \sim 435$

19 『風俗画報』 411 号 1910 年 8 月 5 日, p4 8

20)酒井美意子『ある華族の昭和史』主婦と生活社, 1982 年 2 月 20 日 